\title{
Oral Testament in Distribute Inheritance of Islamic Law Compilation
}

\author{
Nunung Rodliyah \\ Islamic Law Lecturer \\ Lampung University \\ Lampung, Indonesia \\ nunungradliyah@yahoo.com
}

\author{
Ade Oktariatas Ky* \\ Master of Law Science \\ Lampung University \\ Lampung, Indonesia \\ Adeoktariatasky@outlook.com
}

\author{
Hanifah Nuraini \\ Master of Law Science \\ Lampung University \\ Lampung, Indonesia \\ Hanifahwinartin10@gmail.com
}

\begin{abstract}
Oral testament is an example of a nonintellectual type of transfer of rights that frequently causes problems in the community. Factors that frequently develop as a result of heirs' unhappiness with the inheritance distribution. Oral testaments are governed by numerous rules, one of which being the Compilation of Islamic Law (KHI), which is based on Presidential Instruction Number 1 of 1991. This is a normative work that uses descriptive research methods. The following are the findings: first, according to $\mathrm{KHI}$, the legal status of the oral testament in the distribution of inheritance has legal certainty in the national testament's laws. Second, the use of oral testaments in inheritance distribution under the KHI must meet the requirements outlined in Articles 194 and 195 of the KHI. Third, according to KHI, the legal consequences of oral testaments in the distribution of inheritance can be valid if the conditions are met and otherwise invalid if the conditions are not met, with other consequences such as testament cancellation, revocation, and prohibition of things that are prohibited in the implementation of the technique occur.
\end{abstract}

Keywords - Oral Testament, Inheritance, Islamic Law Compilation (KHI)

\section{INTRODUCTION}

The law of bilateral inheritance is following the foundations in Pancasila and the 1945 Constitution, especially Article 27 and Article 29. National Inheritance Law must be soul-based, humane, virtuous nationality, democratic, and anti-feudal [1]. Understanding related to inheritance in connection with material law certainty that occurs the process of transferring ownership rights between someone to the person closest to him.

One system of transferring ownership rights uses the principle namely antarâdhin (likes and likes). This principle implies that the transfer of rights to the property is carried out voluntarily through the process of buying and selling, inheritance, grants, endowments, alms, infaq, zakat, borrowing loans, accounts payable, pawn, or leasing [2]
One form of transfer of rights other than inheritance is a testament, which is the giving of someone to another person, both in the form of objects, accounts receivable, and benefits to be owned by the recipient of the testament as a gift that applies after the death of the person [3].

Not a few cases occur in the community where parents have distributed inheritance to their children with the aim that there will be no disputes later after they die. However, sometimes there will be a sense of injustice over the assets obtained by each child of the heir and prosecutions occurred to divide the inheritance with equal shares.

In practice, things often happen that are not desired related to the implementation of an oral testament in terms of legal certainty regarding ownership of these orally inherited assets. Even though in the view of Islamic law a testament has an important position and always can take precedence, no close possibility of problems or disputes arising from the recipient of the testament or the heirs of the giver of the inheritance.

A testament has been valid if it has been delivered by someone, even if only verbally without writing because the basic law of the declaration is indeed oral [4].

Not a few parties consider oral testaments not enough to provide legal certainty because they are not equipped with the presence of written documents that are authentic and provide more legal certainty. the right is due to not fulfilling the conditions of implementation of the oral testament. Whereas when viewed in the provisions of the Compilation of Islamic Law (KHI), a testament carried out verbally is a legitimate legal action that is carried out following the applicable rules and provides legal certainty for those entitled to it, especially the heirs of the testament [5].

The problems that we discussed in this paper consist of First, what is the legal standing of the testament in the distribution of inheritance according to KHI? 
Second, what is the oral testament to the distribution of inheritance according to KHI? And third, what are the legal consequences of oral testaments in the distribution of inheritance according to KHI?

\section{RESEARCH METHOD}

This research is normative research with a descriptive research type. The approach to the problem used is the juridical-normative approach. The data used are secondary data consisting of primary legal materials, secondary legal materials, and tertiary legal materials, then the data analysis is done in qualitative descriptive.

\section{THEORETICAL STRUCTURE}

\section{A. Inheritance Islamic Law}

The Islamic inheritance legal system is a system of inheritance law regulated in the Qur'an, Sunnah / Hadith, and Ijma and Ijtihad. Pewarisan according to the Islamic inheritance legal system is the process of transferring the inheritance of someone who has died, both in the form of material rights and other rights to the heirs who are declared entitled by law.

According to Habiburrahman, the definition of inheritance (al-mirats) which is also called faraidh is a certain part of inheritance as regulated in the texts of the Qur'an and Hadith, namely the transfer of rights and obligations about the wealth of someone who has died to those who still alive with certain parts that have been set in the texts of the Qur'an and Hadith [6]. The basics of Islamic inheritance law are as follows: Al-Qur'an, As-Sunnah, Ijma, and Ijtihad [7].

Based on the verses of the Qur'an and the hadiths of the Prophet Muhammad concerning Islamic inheritance law as described previously, then several principles must be considered in implementing the inheritance law. The principles of Islamic inheritance law consist of Ijbari Principle, Bilateral Principle, Individual Principle, Fair Justice Principle, and Death Principle [8]

\section{B. Testament}

The legal position of the testament in the Al-Qur'an Al-Baqarah verse 180 and the Al-Maidah verse 106 meaning the two verses are [9]:

Q.S. Al-Baqarah verse 180: meaning: "You must, if one of you comes (signs) death if he leaves a treasure that has many intents for the mother-father and friend of his relatives in a manner, (this is) the obligation of the devoted."

Q.S. Al-Maidah verse 106: meaning: O believers! If one (among) you faces death, while he is going to have an inheritance, then let (the testament) be witnessed by two just men among you, or two different people (religion) with you. If you are on the way to earth then you are in danger of death, let you hold the two witnesses after the prayer so that both of them swear by Allah's name if you doubt, "By Allah, we will not take advantage of this oath, even though he is a close friend, and we do not hide the testimony of God if indeed we are of course sinners."

\section{Written and Oral Testament}

Testament means a message from a person who lives to someone else who lives about something that must be carried out by him after the giver of the message dies. A will has been legitimately submitted by someone, even if only verbally without writing because the basic law of the administration is indeed oral [10].

\section{DISCUSSION OF RESULTS}

\section{A. The legal standing of oral testaments in the distribution of inheritance according to the Compilation of Islamic}

Law

The position of the implementation of this oral testament as in the implementation of ijtihadiyah almaslahah al-mursalah is against the provisions of Islamic law which have not detailed the distribution of oral testaments in the event of inheritance. In terms of language, the word al-maslahah is like lafaz almanfa'at, both it's meaning and vizil (word scales), which is the masdar sentence which means the sentence al-salah, as well as lafaz al-manfa'at, which means alnaf'u. It can also be said that almaslahah is a single form of the word al-masalih. While the meaning of manfa'at as intended by the makers of the syara 'law (Allah SWT) is the nature of guarding religion, soul, mind, descent, and wealth to achieve real border between the Creator and His creatures [11]

Prof. DR. Rachmat Syafe'i in his book entitled "The

Science of Usul Fiqh" [12] explains the meaning of the issue of al-Mursalah more broadly, which is why it is a provision based on the maintenance of kemudharatan or to express a benefit so that the event is called maslahah almursalah. The main purpose of maslahah al-mursalah is a benefit, which is to nurture from kemudharatan and maintain its usefulness.

The implementation of testamentary law verbally is regulated in the Compilation of Islamic Law Article 195 paragraph (1) A testament is carried out verbally in the presence of two witnesses, or written in front of two witnesses, or before a Notary. Based on these provisions legally provide certainty for the validity of the testament orally.

Verdict of oral testament in the Compilation of Islamic Law which has legal certainty is indicated by the provisions governing the testament. The regulated substance is the subject, object, and implementation of the oral testament. The arrangement is expected to be a guideline for the testers and recipients of the testament to be able to fulfill the conditions contained in the Compilation of Islamic Law, especially regarding oral testaments which are only found in the Compilation of Islamic Law. 


\section{B. Implementation of an Oral Testament in the}

Distribution of Inheritance Assets according to the Compilation of Islamic Law

The compilation of Indonesian Islamic Law, especially in the provisions contained in Book II, Chapter V, Article 194 and 195, states that the requirements that must be fulfilled in the implementation of the declaration are as follows [13]:

- The heir must be a person who is 21 years old, has a sound mind, and is based on his volunteerism.

- The inherited property must be the right of the steward.

- The transfer of rights to the goods/objects that are inherited is after the applicant dies.

The requirements that must be fulfilled in the implementation of the assignment are as follows:

- Testament is carried out verbally in front of two witnesses, or written in front of two witnesses, or before a Notary.

- A testament is only permitted as many as onethird of the inheritance unless all heirs agree.

- Testaments to heirs apply if agreed to by all heirs.

- Statement of agreement in paragraphs (2) and (3) of this article is made verbally in the presence of two witnesses or written in front of two witnesses before a Notary.

As for harmony in the implementation of a will, namely: Pillars (elements) testament, namely [14]:

- Heir (al-Munshi)

- Testament recipient

- Assigned assets, namely:

- Testament (Sighat) Editorial.

C. The legal consequences of oral testaments in the distribution of inheritance according to the Compilation of Islamic Law

If the testament verbally does not meet the appropriate requirements, and in the future, there will be parties who object to the testament orally and then submit a claim to the court then the recipient of the will can lose his rights [15]. And if one element of the requirements is not fulfilled, the legal consequences of the oral testament are invalid.

\section{CONCLUSION}

Based on these provisions legally provide certainty for the validity of the will orally in the position of the will of the law in the Compilation of Islamic Law which has legal certainty indicated by the regulations governing the testamentary. The regulated substance is the subject, object, and implementation of the will orally that is. The arrangement is expected to be a guideline for the testers and recipients of the will to be able to fulfill the conditions contained in the Compilation of Islamic Law, especially regarding oral testaments which are only found in the Compilation of Islamic Law.

\section{REFERENCES}

[1] Moh. Mukri, 'Dinamika Pemikiran Fikih Mazhab Indonesia.' Jurnal IAIN Raden Intan Lampung, Vol. 9, No. 2, 2011.

[2] Mohammad Rusfi, 'Filsafat Harta: Prinsip Islam Terhadap Hak Kepemilikan Harta.’ Al-‘Adalah, Vol. 13, No. 2, 2016.

[3] Mardani, Hukum Kewarisan Islam di Indonesia, Jakarta: RajaGrafindo Persada, 2014.

[4] Ahmad Bisryi Syakur, Panduan Lengkap Mudah Memahami Hukum Waris Islam Dilengkapi Hibah dan Wasiat, Jakarta: Visimedia Pustaka, 2015.

[5] http://fh.unram.ac.id, Diakses pada tanggal 21-0121

[6] Syamsulbahri Salihima, Perkembangan Pembagian Warisan dalam Hukum Islam dan Implementasinya pada Pengadilan Agama, Jakarta: Prenamedia Group, 2015.

[7] Achmad Yani, Faraidh dan Mawaris: Bunga Rampai Hukum Waris Islam, Jakarta: Kencana, 2016.

[8] Zainuddin Ali, Pelaksanaan Hukum Waris di Indonesia, Jakarta: Sinar Grafika, 2010.

[9] Nunung Rodliyah, 'Hukum Waris Islam (Buku Ajar), Bandar Lampung: Universitas Lampung, 2012

[10] Adam Lukmanto dan Munsharif Abdul Chalim, 'Tinjauan Hukum dan Akibatnya Terhadap Warisan Tanpa Akta Notaris Ditinjau dari Kompilasi Hukum Islam dan Kitab UndangUndang Hukum Perdata', Jurnal Akta, Vol. 4, No. 1, 2017.

[11] Mohammad Yasir Fauzi, 'Legislasi Hukum Kewarisan di Indonesia', E-Journal IAIN Raden Intan Lampung, Vol. 9, No. 2, 2016

[12] Rachmat Syafe'i, Ilmu Ushul Fiqih, Jakarta: Prenamedia Group, 2010.

[13] Nunung Rodliyah, Hukum Waris, Bandar Lampung: ZamZam Tower, 2017

[14] Adelina Nasution, 'Pluralisme Hukum Waris di Indonesia', AlQadha, Vol. 5, No. 1, 2018.

[15] Nurnazli, 'Kontruksi Hukum Islam Tentang Pembatalan dan Pencabutan Wasiat', Ijtima'iyya, Vol. 9, No. 2, 2016. 